\title{
Evaluation of the applicability of musculoskeletal ultrasonography of the thoracolumbar and lumbar spine segment of healthy $\operatorname{dog}{ }^{1}$
}

\author{
Érika R. Lopes², Gabriela M.C. Bellegard², Fábio S. Cury², Felipe A.S. Abreu³, \\ Carlos E. Ambrósio ${ }^{2}$, Adriano B. Carregaro ${ }^{2}$ and Maria Cristina F.N.S. Hage ${ }^{2 *}$
}

\begin{abstract}
Lopes E.R., Bellegard G.M.C., Cury F.S., Abreu F.A.S., Ambrósio C.E., Carregaro A.B. \& Hage M.C.F.N.S. 2018. Evaluation of the applicability of musculoskeletal ultrasonography of the thoracolumbar and lumbar spine segment of healthy dogs. Pesquisa Veterinária Brasileira 38(12):2278-2283. Setor de Diagnóstico por Imagem, Faculdade de Zootecnia e Engenharia de Alimentos, Universidade de São Paulo, Av. Duque de Caxias Norte 225, Zona Rural, Pirassununga, SP 13635-900, Brazil. E-mail: crishage@usp.br

Changes in the spine of dogs are usually detected in clinical and in surgical practice. Few studies exist on musculoskeletal ultrasound anatomy of the thoracolumbar and lumbar segments of the normal spine of dogs. This study aimed to compare the normal musculoskeletal ultrasound anatomy of the T10-S1 vertebral segments with images obtained with magnetic resonance imaging (MRI), computed tomography (CT), and anatomical structures, and to establish the ability to identify structures using these modalities. Ultrasound scans allowed visualization of the muscles of the region, articular processes, spinous process, interspinous ligament, and yellow ligament in the lumbosacral window. Computed tomography images provided better bone details, compared to ultrasound images. Low-field MRI allowed the identification of the same structures identified with ultrasound imaging, and allowed the identification of cerebrospinal fluid, transverse processes, and provided improved detail of the intervertebral discs and spinal cord. Knowledge of ultrasound anatomy of the region may allow the the identification of muscle and ligament injuries. Thus, in cities where CT and MRI are inaccessible, ultrasonography of the region could be a good alternative to identify possible changes not observable with radiographic examination or to complement radiographic examination.
\end{abstract}

INDEX TERMS: Musculoskeletal ultrasonography, thoracolumbar, lumbar spine, healthy dogs, skeleton, muscle, vertebra.

RESUMO.- [Avaliação da aplicabilidade da ultrassonografia musculoesquelética do segmento toracolombar e lombar da coluna vertebral de cães hígidos.] Alterações na coluna vertebral de cães são comumente encontradas na rotina clínica e cirúrgica veterinária. Existem poucos estudos

\footnotetext{
${ }^{1}$ Received on April 10, 2018.

Accepted for publication on May 2, 2018.

${ }^{2}$ Setor de Diagnóstico por Imagem, Faculdade de Zootecnia e Engenharia de Alimentos (FZEA), Universidade de São Paulo (USP), Av. Duque de Caxias Norte 225, Zona Rural, Pirassununga, SP 13635-900, Brazil. E-mails: erika_rondon10@hotmail.com, gabi_bellegard@hotmail.com, fcury@usp.br, ceambrosio@usp.br, carregaro@usp.br; *Corresponding author: crishage@usp.br

${ }^{3}$ Provet, Medicina Veterinária Diagnóstica, Avenida Aratãs 1009, Moema, São Paulo, SP 04081-004, Brazil. E-mail: felipeasa@hotmail.com
}

sobre a anatomia ultrassonográfica musculoesquelética do segmento toracolombar e lombar da coluna vertebral normal de cães. $O$ objetivo deste trabalho foi comparar a anatomia ultrassonográfica musculoesquelética normal dos segmentos vertebrais T10-S1 com imagens obtidas pela ressonância magnética, tomografia computadorizada e peças anatômicas visando demonstrar a sua capacidade de identificação de estruturas. A varredura ultrassonográfica permitiu a visibilização da musculatura da região, processos articulares, processos espinhosos, ligamentos interespinhosos e ligamento amarelo na janela lombossacra. A tomografia computadorizada forneceu imagens com melhor detalhamento ósseo quando comparada ao exame ultrassonográfico. A ressonância magnética de baixo campo permitiu a identificação das mesmas estruturas 
que o exame ultrassonográfico acrescido da identificação do líquido cerebroespinal, processos transversos e melhor detalhamento dos discos intervertebrais e medula espinhal. Com o conhecimento da anatomia ultrassonográfica da região, acredita-se que lesões musculares e ligamentares possam ser identificadas. Vale salientar que em cidades onde a tomografia computadorizada e a ressonância magnética não estejam acessíveis a ultrassonografia da região pode ser uma boa alternativa para identificar possíveis alterações não visibilizadas ao exame radiográfico, ou complementá-lo.

TERMOS DE INDEXAÇÃO: Ultrassonografia musculoesquelética, toracolombar, coluna lombar, cães sadios, esqueleto, musculatura, ultrassom, vértebra.

\section{INTRODUCTION}

Several imaging techniques are used to assess the canine spine. The most common techniques include simple radiography, myelography, computed tomography (CT), and magnetic resonance imaging (MRI) (Emery et al. 2018, Noyes et al. 2017).

Ultrasonography is a widely available and low-cost imaging diagnostic technique, compared to CT and MRI. The combination of high-definition ultrasound equipment and trained professionals can provide similar information or additional information as that obtained through MRI of the vertebral musculature (Samii \& Long 2005).

The literature contains extensive descriptions of the use of ultrasonography on equine limbs (Dowling et al. 2000) and on the spinal column (Fonseca et al. 2006, Vandeweerd et al. 2007, Fuglbjerg et al. 2010) to aid the collection of cerebrospinal fluid from the cisterna magna and to evaluate the lumbosacral space (Aleman et al. 2007). In small animals, the use of ultrasonography to assess the musculoskeletal system has been growing (Samii \& Long 2005). There are reports on its use to evaluate the shoulder (Long \& Nyland 1999), long bones (Risselada et al. 2003), elbow (Lamb \& Wong 2005), cisterna magna in dogs with Chiari malformations (Schmidt et al. 2008), and ultrasound anatomy of the cervical spine (Sarto et al. 2014). However, few studies exist on the ultrasound anatomy of the lumbar spine and guided lumbar puncture (Garcia et al. 2018, Monticelli et al. 2017, Etienne et al. 2010), and no study exists on the ultrasound anatomy of the T10-S1 region. This study thus aimed to test the ultrasonographic technique to assess the thoracolumbar and lumbar segments of the spine of dogs, and to evaluate its potential applicability in this region.

\section{MATERIALS AND METHODS}

After obtaining approval by the ethics committee of the Faculty of Animal Science and Food Engineering at the University of São Paulo, Faculdade de Zootecnia e Engenharia de Alimentos, Universidade São Paulo (FZEA-USP) (Pirassununga/SP, Brazil, approval no. 14.1.1469.74.1), studies were conducted on anatomical structures obtained from the FZEA-USP Veterinary Anatomy Laboratory and from animals that died in private clinics in the city of Pirassununga, Brazil. After anatomically identifying the structures, 10 live dogs were screened radiographically. All animals with radiographic evidence of alterations in the structures were excluded from the experiment. The selected animals underwent a complete blood count and measurement of the levels of urea and creatinine, alanine aminotransferase, aspartate aminotransferase, and alkaline phosphatase. Dogs with no abnormal blood test results were anesthetized for radiographic examination of the laterolateral and ventrodorsal projections along the entire spine. After screening, the T10-S1 segments of the spine of 10 healthy animals were assessed ultrasonographically by using the dorsal approach. After the descriptive studies of the anatomical structures and x-ray and ultrasonographic evaluations, an ultrasonically examined animal was selected to undergo CT and MRI scans.

Local. The anatomical study and the preparation of anatomical structures were conducted at the Veterinary Anatomy Laboratory of the Faculty of Animal Science and Food Engineering of the University of São Paulo (FZEA-USP, Pirassununga/SP, Brazil). The thoracolumbar and lumbar segments of the spine of the dogs were also evaluated using radiography and ultrasound in the Diagnostic Imaging Division of the FZEA-USP. The CT scans were performed in the Diagnostic Imaging Division of the School of Veterinary Medicine and Animal Science, Universidade Estadual Paulista (Unesp), Botucatu/SP, Brazil), and the MRI scans were conducted at the Provet Veterinary Diagnostic Medicine in Moema/SP, Brazil.

Anatomical structures assessment. The anatomy laboratory provided anatomical structures and other three animals that died in private clinics in the city of Pirassununga. The three corpses were frozen in an upright position. Thereafter, sections were cut in the transverse plane with the aid of a band saw (Siemens, Munich, Germany).

The anatomical structures were photographed. The collected data and images of the anatomical structures were compared with the images obtained by radiography, ultrasonography, MRI, and CT scans of the region (Dyce et al. 2010, Evans \& De Lahunta 2012, Wisner \& Zwingenberger 2015).

Radiographic examination. The selected animals underwent chemical restraint with preanesthetic medication (PAM), which consisted of acepromazine $(0.05 \mathrm{mg} / \mathrm{kg})$ and morphine $(0.5 \mathrm{mg} / \mathrm{kg})$ administered intramuscularly. Radiographic examinations were administered to some animals in which PAM medication provided sufficient relaxation. Animals that did not relax with PAM were induced with intravenous propofol $(5 \mathrm{mg} / \mathrm{kg})$, and anesthesia was then maintained by isoflurane inhalation. Heart rate, respiratory rate, and rectal temperature were monitored while the dogs completely recovered. On recovery, they were returned to their owners.

After anesthesia, the animals were placed in the laterolateral and the ventrodorsal decubitus positions, and serial radiographs of the entire spine were obtained in each position. The radiographic apparatus used was the Altus ST generator (Sawae Tecnologia Ltd., Nova Lima/MG, Brazil) $630 \mathrm{~mA}$ and $125 \mathrm{kV}$ with rotating anode $\mathrm{x}$-ray ampoule, and equipped with a radiological table with a fixed grid. The radiographic films were placed in a metal chassis equipped with intensifying screens that were suitable for the size of the animal. The development and fixation of the films took place in an automated X-ray film processor (LX-2; Lotus, Curitiba, Paraná, Brazil).

Radiographic examinations were conducted using radiological protection standards. The veterinarians involved in the examination used lead aprons that were $0.5 \mathrm{~mm}$ thick in the front and $0.25 \mathrm{~mm}$ thick in the back, a $0.50-\mathrm{mm}$ thick thyroid lead protector, and $0.50 \mathrm{~mm}$ lead gloves. The technique was based on the correlation between kilovoltage and milliamperage, according to the thickness of the evaluated segment. The animals were radiographed in the ventrodorsal and laterolateral projection to assess the entire spine.

Ultrasound examination. Ultrasonography was conducted with the MyLab Class C Vet ultrasound device (Esaote, Genoa, Italy), which was equipped with an electronic linear transducer (LA 533) of 8-13 MHz. The procedure started with trichotomy of the region of 
study with a shearing machine and subsequent application of acoustic gel. The animals were maintained in left lateral decubitus with the thoracic limbs parallel and cranially extended and the pelvic limbs parallel and cranially extended. First, the images were acquired in B-mode in the median longitudinal and paramedian plane and later in the transversal plane to analyze the segments of the sacrum at the 10th thoracic vertebra. Ultrasound scanning started with L7-S1 because this region allowed easier visualization, and was followed cranially segment by segment until reaching T10-T11.

Computed tomography scan. An animal undergoing a CT scan was anesthetized. The PAM included acepromazine $(0.02 \mathrm{mg} / \mathrm{kg})$ and morphine $(0.5 \mathrm{mg} / \mathrm{kg})$, and was administered intramuscularly. The animal was then induced with intravenous propofol $(3.5 \mathrm{mg} / \mathrm{kg})$, and anesthesia was maintained with isoflurane until the end of the procedure. Heart rate, respiratory rate, and rectal temperature were monitored until stabilization. The animal was then returned to the owner.

The images used in the study were obtained with a CT scanner ${ }^{1}$. The technique settings were $120 \mathrm{kV}$ and $160 \mathrm{~mA}$ with 2 seconds of acquisition time, a cut thickness of $2 \mathrm{~mm}$, and a cut-off interval of $2 \mathrm{~mm}$; scanning was conducted without contrast from the 10th thoracic vertebra to the lumbosacral region. The CT images were obtained in transverse plane and then the sagittal reconstructions were performed. The soft tissue and bone windows were used in the tomographic images, based on the technique of Tidwell (2010).

Magnetic resonance imaging. Dogs that underwent MRI were anesthetized. Acepromazine $(0.03 \mathrm{mg} / \mathrm{kg})$ and pethidine $(3 \mathrm{mg} / \mathrm{kg})$ were administered intramuscularly. The animals were then induced with propofol $(3 \mathrm{mg} / \mathrm{kg})$ and midazolam $(0.2 \mathrm{mg} / \mathrm{kg})$. Isoflurane was used to maintain anesthesia until the end of the procedure. Heart rate, respiratory rate, and rectal temperature were monitored until complete stabilization. The animal was then returned to the owner.

The images were acquired through $\mathrm{MRI}^{2}$. The imaging planes were the transverse and sagittal planes. The images were acquired in T1-weighted spin echo (SE) and T2-weighted fast spin echo (FSE) sequences.

\section{RESULTS}

In this study, it was possible to observe the hyperechoic laminar appearance of the skin with ultrasonographic examination. The subcutaneous tissues had hypoechogenic areas with hyperechogenic sites.

The lumbar multifidus and longissimus muscles in the longitudinal plane were hypoechogenic and the muscular fascias exhibited echogenic streaks. In the transverse plane, the muscles were hypoechogenic with echogenic foci (Fig.1).

The bone surface of each vertebra had a hyperechogenic line that produced an acoustic shadow (Fig.1).

The 2-mm thick vertebral segments evaluated through the tomographic examination provided good bone detail of the vertebrae.

Magnetic resonance imaging allowed the visualization of more structures with better image definition, compared to other imaging techniques (Table 1). Yellow and interspinous ligaments were only observed through ultrasonography examination (Fig.2).

\footnotetext{
1 Shimadzu, model SCT-7800. Kyoto, Japan.

2 Esaote, model Vet MR large 0.3 Tesla and column coil number 13. Genoa, Italy.
}

The T1-weighted SE MRI images allowed visualization of the musculature with improved definition, compared with T2-weighted FSE images. The T2-weighted images allowed
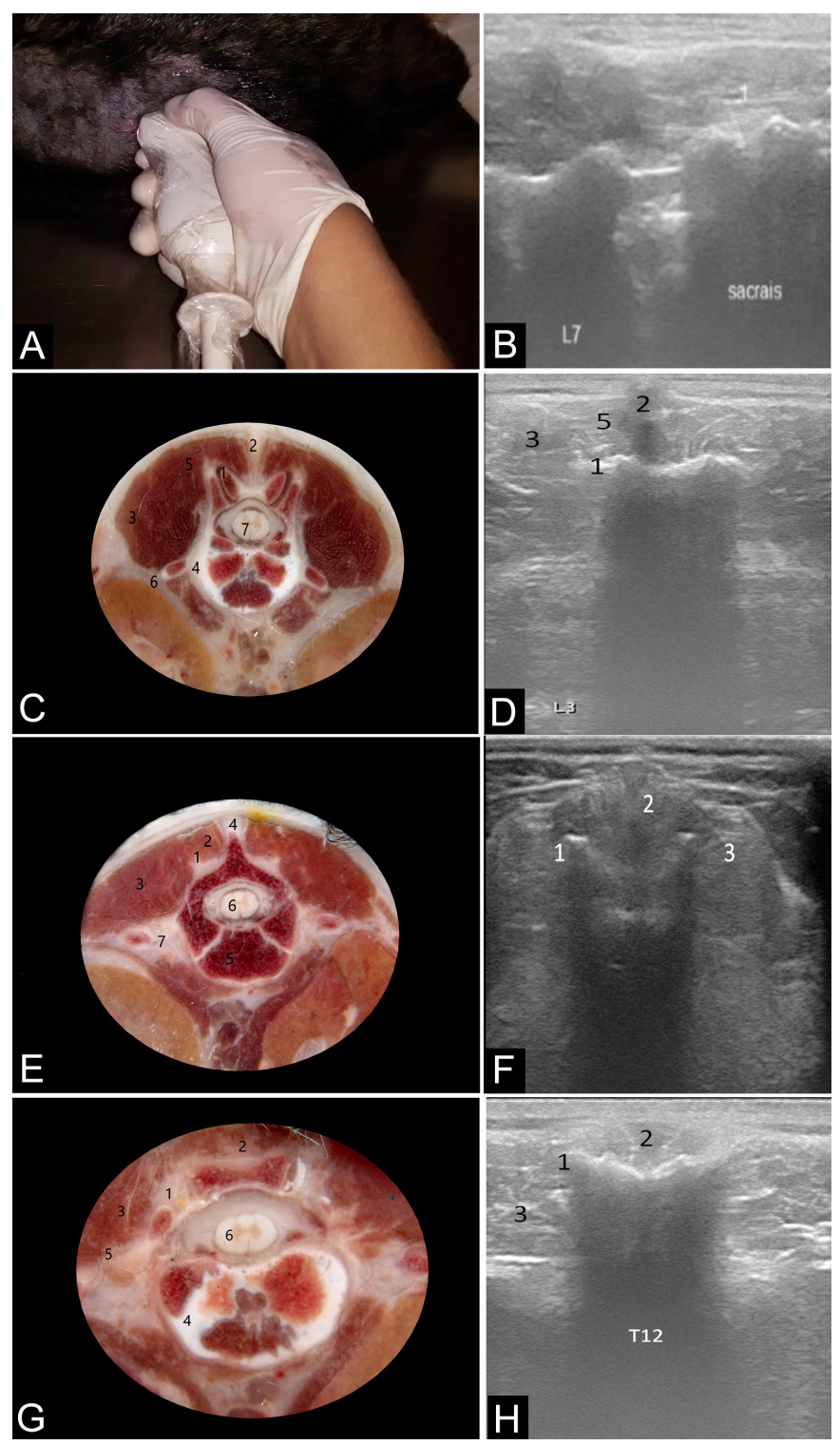

Fig.1. Ultrasound planes and images. (A,B) Paramedian longitudinal plane of a dog's lumbosacral region. The number " 1 " indicates the lumbar multifidus muscle. Transverse planes in the anatomical section and the corresponding ultrasound image. (C,D) The third lumbar vertebra (L3) region. The numbers indicate the following anatomical structures: joint processes (1), spinal process (2), lumbar longissimus muscle (3), third lumbar vertebra (4), lumbar multifidus muscle (5), transverse process (6), spinal cord (7). (E,F) The 13th thoracic vertebra (T13) region. The numbers indicate the following anatomical structures: joint process (1), thoracic and lumbar multifidus muscle (2), longissimus thoracic and lumbar muscle (3), spinous process (4), 13th thoracic vertebra (5), spinal cord (6), transverse process (7). (G,H) The 12th thoracic vertebra (T12) region. The numbers indicate the following anatomical structures: joint process (1), thoracic multifidus and lumbar muscles (2), longissimus thoracic and lumbar muscle (3), twelfth thoracic vertebra (4), transversal process (5), spinal cord (6). 
Table 1. Visible structures in the imaging scans and the respective quality of the visualization

\begin{tabular}{|c|c|c|c|c|}
\hline \multirow{2}{*}{ Structures } & \multicolumn{4}{|c|}{ Imaging techniques } \\
\hline & XR & US & MR & $\mathrm{CT}$ \\
\hline Skin & - & +++ & ++ & - \\
\hline Subcutaneous & - & +++ & ++ & - \\
\hline Muscle fascia & - & +++ & - & - \\
\hline Epaxial muscles & - & +++ & +++ & + \\
\hline Hypaxial muscles & - & - & +++ & + \\
\hline Cortical bone & ++ & $+*$ & +++ & +++ \\
\hline Spinal cancellous bone & - & - & +++ & +++ \\
\hline Joint processes & + & ++ & + & +++ \\
\hline Spinous process & ++ & ++ & +++ & +++ \\
\hline Transverse process & ++ & + & +++ & +++ \\
\hline Vertebral body & ++ & - & +++ & +++ \\
\hline Spinal canal & ++ & - & +++ & +++ \\
\hline Spinal cord & - & - & +++ & + \\
\hline Interspinous ligament & - & +++ & - & - \\
\hline Yellow ligament & - & ++ & - & - \\
\hline Intervertebral space & ++ & ++ & +++ & +++ \\
\hline Intervertebral disc & - & - & +++ & - \\
\hline Cerebrospinal fluid & - & - & +++ & - \\
\hline
\end{tabular}

$\overline{\mathrm{XR}}=\mathrm{X}$-ray, US = ultrasound, $\mathrm{CT}=$ computed tomography, $\mathrm{MR}=$ magnetic resonance; __ unidentified structure, + poorly visible structure, $+{ }^{*}$ bone surface only, ++ moderate visibility of the structure, +++ optimal visibility of the structure.

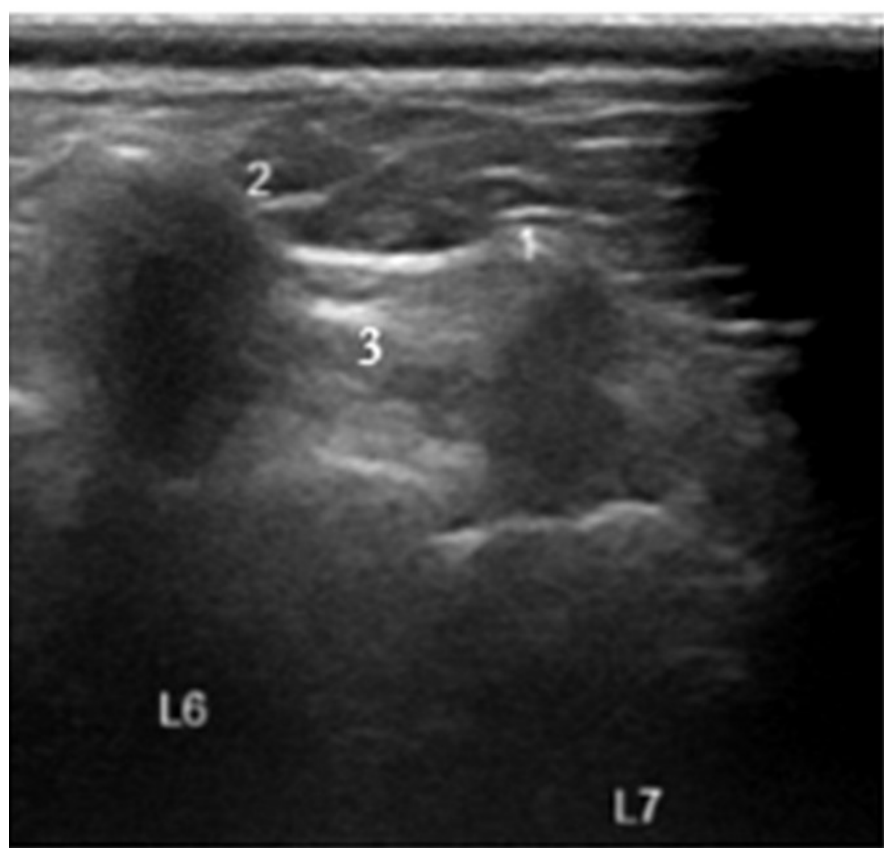

Fig.2. Ultrasound image of the spine in the longitudinal paramedian oblique plane demonstrates the interspinous ligament between L6 and L7. The numbers indicate the following anatomical structures: L7 spinous process (1), L6 spinous process (2), interspinous ligament (3).

the intervertebral disc nucleus and cerebrospinal fluid to be observed.

The correlation between diagnostic imaging methods and anatomical structures are shown in Table 1.

\section{DISCUSSION}

This study confirmed that it is necessary to have anatomical knowledge of the evaluated structures for a correct ultrasonographic evaluation of the spine. Thus, the study of corpses and the execution of cross-sections in frozen anatomical structures were essential for correctly applying the ultrasonographic technique, which was also confirmed by other authors (Berg et al. 2003).

The lumbar and thoracic vertebrae were easily identified on ultrasound examination. However, it is worth mentioning some difficulties associated with the examination such as maintaining an animal in the correct position, the difficulty of maintaining the transducer in the same place to facilitate counting the vertebrae, the veterinarian's experience in performing the procedure, and the lack of studies on the topic.

A linear 8-13 MHz transducer provided adequate definition of the evaluated vertebral structures. This finding was similar to the results obtained by other researchers (Samii \& Long 2005, Sarto et al. 2014) who used 5-10 MHz linear transducers in ultrasound studies of the cervical spine of dogs. The better definition of the image using linear transducers is because of their high frequency, which provides a higher resolution of the image.

Visualization of the musculature details may vary with different types of equipment and with the frequency of the transducer; however, the findings are usually a hypoechogenic structure interspersed by hyperechogenic lines with variable organization, depending on the plane approach. The quality of the devices and transducers and the varying frequencies will impact image quality. An acoustic pad may be required when using a transducer with a frequency lower than the frequency suggested in the literature. The trichotomy of the region may also provide enhanced acoustic coupling in these instances, and thereby improve the image. Despite these variations, the image of the musculature is characteristic and easy to recognize

Similar to the results obtained by Kramer et al. (1997), the bone surface of each vertebra revealed a hyperechogenic line that produced a posterior acoustic shadow. This phenomenon is associated with the difference in acoustic impedance between the soft structures and the bone tissue. This difference causes a sharp reflection of the sound beams back to the transducer, which provides a hyperechogenic line effect on the bone surface and consequently an acoustic shadow. In the current study, the interspinous yellow ligaments were observed, which was in contrast to the findings of previous reports (Chhem et al. 1994) that claim that these ligaments cannot be observed because of their small size and proximity to the bone surfaces (with the exception of the ligaments of the knee). The differences between the equipment used may have contributed to the discrepancy in the observation of the aforementioned ligaments.

In this study, the use of CT, as previously described by Assheuer \& Sager (1997), provided better bone detail. However, accurately differentiating soft tissues was not possible. Therefore, the use of ultrasonography was important as a complementary technique that provided better detail of the muscles of the T10-S1 segment of the spine; allowed visualization of the musculature; and, because it is a dynamic examination, allowed for muscle contractions, as reported by Kramer et al. (1997). Thus, ultrasonography provides a 
dynamic evaluation of the musculature and can be explored in dogs while placing the spine in different positions (i.e., neutral, extended, and flexed), which allows the ability to investigate variations in muscle thickness and possibly view adhesions between skin and musculature, cicatricial retractions, muscular atrophy, et al. Of course, it loses with respect to the potential of evaluation in humans who are able to perform muscular movements and contractions in a voluntary and directed way, further improving the possibilities of interpretation of the images.

Ultrasound imaging showed a wealth of details in muscle tissue and adjacent regions (e.g., skin, the subcutaneum, muscular fascia) and the possibility of real-time evaluation, compared with CT imaging in which muscle tissues exhibited the same attenuation, which hindered the identification of individual muscles (it was also a static image). By contrast, the ultrasound examination allowed the differentiation of the longissimus and multifidus muscles. The thoracic (T10-T13) and lumbar vertebrae were identified with better detail in the bone window where it was possible to view the articular processes, dorsal arch, vertebral canal, vertebral body, spinal process, and transverse processes. No contrast was administered in the CT scan; therefore, individualization of the spinal cord was not possible.

The 2-mm thick sections in the CT scan allowed adequate detail of the structures, which was consistent with the findings of some authors who studied the cervical spine and recommended a 2-mm maximum. A greater cutting thickness can result in loss of detail because the larger voxel will show the average of the Hounsfield units in the pixel used to form an image, and dilute the minimum and maximum values that would create contrast.

Magnetic resonance imaging allowed the visualization of more structures and allowed improved definition, compared to other imaging techniques (Table 1). This finding was consistent with that of Bagley et al. (2009) who stated that MRI is the gold standard for evaluating the spine and spinal cord. However, visualization of the yellow and interspinous ligaments was only possible through ultrasonography examination. For instance, if 1.5-7 T closed-field MRI equipment was used, the signal conspicuity may be more intense, even in anatomical regions with low signal. This factor allowed a contrast between these structures and improved their visualization. The latter should be investigated in future studies. In this study, two pulse sequences and two imaging planes (i.e., transversal and sagittal) were used to identify most anatomical structures. The T1-weighted SE images allowed visualization of the musculature with enhanced definition, compared with the T2-weighted FSE images. The T1-weighted images provide an optimal representation of the anatomy, although these images have lower water contrast, compared to T2-weighted images (Dennis 2011). The contrast between differences in the concentrations of water molecules in the tissues was higher in T2-weighted images, which allowed visualization of the intervertebral disc nucleus and the cerebrospinal fluid; however, the identification of muscular structures presented a greater degree of difficulty in these images, compared with the T1-weighted images. A better quality signal of the musculature may be possible by using equipment with a greater magnetic field intensity. However, the detail of the musculature was superior with the ultrasonographic method, compared to the 0.3 T signal intensity open field equipment used.

Computed tomography and MRI scans of the spine were performed on a single animal to obtain illustrative images of our own for comparison purposes. Computed tomography and MRI atlases describing spinal findings have been published. Therefore, this focus was not the purpose of this study.

The three imaging methods (i.e., ultrasound, CT, and MRI) have limitations and advantages that complement each other, as presented in Table 1. However, the high availability and low cost of ultrasound equipment, compared to other equipment; its portability; and the ability to identify various structures of the spine region using this modality indicate it as the reference screening method of the spine that can be used by trained technicians.

\section{CONCLUSION}

In this study, B-mode ultrasound examination allowed optimal visualization of the perivertebral musculature and the interspinous and yellow ligaments, compared with other imaging techniques.

Acknowledgements. The authors thank the São Paulo Research Foundation (Fundação de Amparo à Pesquisa de São Paulo, FAPESP - São Paulo/SP, Brazil) and Coordenação de Aperfeiçoamento de Pessoal de Nível Superior (CAPES) (FAPESP Process No. 2014/13893-6) for the grant and technical assistance during the period of this Master's thesis. The authors thank Prof. Luiz Carlos Vulcano by computerized tomography examination (Universidade Estadual Paulista/UNESP-Botucatu).

\section{REFERENCES}

Aleman M., Borchers A., Kass H.P. \& Puchalski S.M. 2007. Ultrasound-assisted collection of cerebrospinal fluid from the lumbosacral space in equids. J. Am. Vet. Med. Assoc. 230(3):378-384. <http://dx.doi.org/10.2460/ javma.230.3.378> <PMid:17269870>

Assheuer J. \& Sager M. 1997. MRI and CT Atlas of the Dog. Blackwell Science, Oxford. 400p.

Bagley R.S., Gavin P.R. \& Holmes S.P. 2009. Diagnosis of spinal disease, p.123-226. In: Gavin P.R. \& Bagley R.S. (Eds), Practical Small Animal MRI. Wiley-Blackwell, Iowa. <http://dx.doi.org/10.1002/9780813810324.ch2a>

Berg L.C., Nielsen J.V., Thoefner M.B. \& Thomsen P.D. 2003. Ultrasonography of the equine cervical region: a descriptive study in eight horses. Equine Vet. J. 35(7):647-655.<http://dx.doi.org/10.2746/042516403775696311> <PMid:14649355>

Chhem R.K., Kaplan P.A. \& Dussault R.G. 1994. Ultrassonography of the musculoskeletal system. Radiol. Clin. N. Am. 32(2):275-289. <PMid:8140227>

Dennis R. 2011. Optimal magnetic resonance imaging of the spine. Vet. Radiol. Ultrasound 52(Suppl.1):S72-S80. <http://dx.doi. org/10.1111/j.1740-8261.2010.01787.x><PMid:21392159>

Dowling B.A., Dart A.J., Hodgson D.R. \& Smith R.K. 2000. Superficial digital flexor tendonitis in the horse. Equine Vet. J. 32(5):369-378. <http://dx.doi. org/10.2746/042516400777591138> <PMid:11037257>

Dyce K.M., Sack W.O. \& Wensing C.J.G. 2010. Tratado de Anatomia Veterinária. Elsevier, Rio de Janeiro. 840p.

Emery L., Hecht S. \& Sun X. 2018. Investigation of parameters predicting the need for diagnostic imaging beyond computed tomography in the evaluation of dogs with thoracolumbar myelopathy: retrospective evaluation of 555 dogs. Vet. Radiol. Ultrasound 59(2):147-154. <PMid:29160005> 
Etienne A.L., Peeters D. \& Busoni V. 2010. Ultrasonographic percutaneous anatomy of the caudal lumbar region and ultrasound-guided lumbar puncture in the dog. Vet. Radiol. Ultrasound 51(5):527-532.<http://dx.doi. org/10.1111/j.1740-8261.2010.01705.x><PMid:20973387>

Evans E. \& De Lahunta A. 2012. Miller's Anatomy of the Dog. 4th ed. W.B. Saunders, Philadelphia. 872p.

Fonseca B.P.A., Alves A.L.G., Nicoletti J.L.M., Thomassian A., Hussni C.A. \& Mikail S. 2006. Thermography and ultrasonography in back pain diagnosis of equine athletes. J. Equine Vet. Sci. 26(11):507-516. <http://dx.doi. org/10.1016/j.jevs.2006.09.007>

Fuglbjerg V., Nielsen J.V., Thomsen P.D. \& Berg L.C. 2010. Accuracy of ultrasound-guided injections of thoracolumbar articular process joints in horses: a cadaveric study. Equine Vet. J. 42(1):18-22. <http://dx.doi. org/10.2746/042516409X454565><PMid:20121908>

Garcia K.M., Harrison M.F., Sargsyan A.E., Ebert D. \& Dulchavsky S.A. 2018. Real-time ultrasound assessment of astronaut spinal anatomy and disorders on the international space station. J. Ultrasound Med. 37(4):987-999. <http://dx.doi.org/10.1002/jum.14438><PMid:28960477>

Kramer M., Gerwing M., Hach V. \& Schimke E. 1997. Sonography of the musculoskeletal system in dogs and cats. Vet. Radiol. Ultrasound 38(2):139-149. <http://dx.doi.org/10.1111/j.1740-8261.1997.tb00829. $\mathrm{x}><$ PMid:9238783>

Lamb C.R. \& Wong K. 2005. Ultrasonographic anatomy of the canine elbow. Vet. Radiol. Ultrasound 46(4):319-325. <http://dx.doi. org/10.1111/j.1740-8261.2005.00060.x><PMid:16229434>

Long C.D. \& Nyland T.G. 1999. Ultrasonographic evaluation of the canine shoulder. Vet. Radiol. Ultrasound 40(4):372-379. <http://dx.doi. org/10.1111/j.1740-8261.1999.tb02129.X ><PMid:10463832>

Monticelli P., Jones I. \& Viscasillas J. 2017. Ultrasound-guided thoracic paravertebral block: cadaveric study in foxes (Vulpes vulpes). Vet. Anaesth.
Analg. 44(4):968-972. <http://dx.doi.org/10.1016/j.vaa.2016.06.007> <PMid:28728944>

Noyes J.A., Thomovsky S.A., Chen A.V., Owen T.J., Fransson B.A., Carbonneau K.J. \& Matthew S.M. 2017. Magnetic resonance imaging versus computed tomography to plan hemilaminectomies in condrodystrofic dogs with intervertebral disc extrusion. Vet. Surg. 46(7):1025-1031. <http://dx.doi. org/10.1111/vsu.12700 > <PMid:28834552>

Risselada M., Kramer M. \& Van Bree H. 2003. Approaches for ultrasonographic evaluation of long bones in the dog. Vet. Radiol. Ultrasound 44(2):214-220. <http://dx.doi.org/10.1111/j.1740-8261.2003.tb01274.x><PMid:12718359>

Samii V.F. \& Long C.D. 2005. Sistema musculoesquelético, p.273-291. In: Mattoon J.S. \& Nyland T.G. (Eds), Ultra-som Diagnóstico em Pequenos Animais. Roca, São Paulo.

Sarto C.G., Hage M.C.F.N.S., Guimarães L.D., Giglio R.F., Borges A.P.B. \& Vulcano L.C. 2014. The role of B-mode ultrasonography in the musculoskeletal anatomical evaluation of the cervical region of the dog spine. Pesq. Vet. Bras. 34(1):91-97. <http://dx.doi.org/10.1590/S0100-736X2014000100015>

Schmidt M.J., Wigger A., Jawinski S., Golla T. \& Kramer M. 2008. Ultrasonographic appearance of the craniocervical junction in normal brachycephalic dogs and dogs with caudal occipital (Chiari-like) malformation. Vet. Radiol. Ultrasound 49(5):472-476. <http://dx.doi.org/10.1111/j.1740-8261.2008.00411.x> <PMid:18833958>

Tidwell A.S. 2010. Princípios da tomografia conputadorizada e da imagem por ressonância magnética, p.50-77. In: Trhall D.E. (Eds), Diagnóstico de Radiologia Veterinária. Elsevier, Rio de Janeiro.

Vandeweerd J.M., Desbrosse F., Clegg P., Hougardy V., Brock L., Welch A. \& Cripps P. 2007. Innervation and nerve injections of the lumbar spine of the horse: a cadaveric study. Equine Vet. J. 39(1):59-63. <http://dx.doi org/10.2746/042516407X153147><PMid:17228597>

Wisner E.R. \& Zwingenberger A.L. 2015. Atlas of Small Animal CT and MRI. WileyBlackwell, Philadelphia. 704p. <http://dx.doi.org/10.1002/9781119421399> 